\title{
THE RELATIONSHIP BETWEEN INTERPERSONAL PROBLEM SOLVING, POSITIVE - NEGATIVE AFFECT AND ANXIETY
}

\author{
Ahmet BEDEL \\ Department of Guidance \& Psychological Counseling, Education Faculty, Mevlana University \\ 235 Yeni İstanbul Street, 42003 Selçuklu, Konya, Turkey \\ E-mail: abedel@mevlana.edu.tr
}

\begin{abstract}
The purpose of this study was to examine the relationships of interpersonal problem solving, positive-negative affect and anxiety. To this end, 336 high school students completed Interpersonal Problem Solving Inventory (Çam \& Tümkaya, 2008), Positive and Negative Affect Schedule (Gençöz, 2000), and Trait Anxiety Inventory (Öner, 1977). The statistical analysis of the study included Pearson Moments Correlation Coefficient and Multiple Regression Analysis. The results indicated that intercorrelations among negative orientation to the problem, negative affect, anxiety, and intercorrelations among constructive problem solving, insistentpersevering orientation and positive affect were all significant. Results of Multiple Regression Analysis indicated that within negative affect and anxiety, negative orientation to the problem was the most powerful predictor. In light of these findings, suggestions for planned interventions to improve interpersonal problem-solving skills of students in individual and group guidance activities are emphasized and ideas for future research are discussed.
\end{abstract}

Key words: interpersonal problem solving, positive and negative affect, anxiety

\section{Introduction}

There are personal differences with respect to the reactions developed against solving interpersonal problems, which stand out as natural integrants of daily life. Social problem-solving model developed by D'Zurilla and Goldfried (1971) with the aim of solving interpersonal problems, consists of problemsolving orientation and problem-solving skill. In this model problem orientation encompasses positive problem orientation and negative problem orientation. In the process of solving an interpersonal problem, the views and perceptions of adolescents towards a particular problem are influential in their problem orientation (Arslan, 2010). Having a positive problem orientation assists an individual in further developing it and employing a functional problem solving skill. The Positive Problem Orientation Scale taps a constructive, cognitive problem-solving ability of an individual that involves a general disposition to appraise a problem as a beneficial opportunity, a belief that problems are solvable, a trust in one's personal ability to solve problems effectively and a belief that successful problem solving requires time, effort and persistence (D'Zurilla, Chang, \& Sanna, 2003). A negative orientation to the problem, on the other hand, is termed as Negative Problem Orientation. Negative Problem Orientation is the orientation to-

DOI: $10.21909 / \mathrm{sp} .2015 .02 .688$ 
wards a dysfunctional problem. Negative Problem Orientation involves the general tendency to view a problem as a significant threat to one's well-being (psychological, social, economical), to doubt one's own ability to solve problems successfully (low problem solving self-sufficiency) and to easily become upset and frustrated when confronted with problems (low tolerance towards frustration) (D'Zurilla, Nezu, \& MaydeuOliveras, 2004).

The social problem-solving model recognizes the following three problem-solving skill styles: rational, impulsivity-carelessness and avoidance. Rational problem solving is a constructive problem-solving skill (Eskin, 2009). Impulsivity-carelessness style is a dysfunctional problem-solving pattern. This pattern is characterized by problem-solving attempts that are narrow, impulsive, hurried and incomplete. The individual possesses very few alternative solutions and most of the times s/he acts impulsively in line with the very first idea occurring. In addition, the person faces challenges in constructing alternative solutions and hardships in construing the potential results of each alternative solution. Avoidance style is another type of dysfunctional problem solving skill. Instead of coping with the problem the individual chooses to avoid it. $\mathrm{S} /$ he procrastinates, and waits until it is solved by itself (D'Zurilla et al., 2004).

It is only natural that different people develop different orientation and problemsolving skills in the face of problems they encounter. Due to their age, it is inevitable that children and adolescents find it rather hard to solve their problems independently (Y1k1lmaz \& Hamamc1, 2011). They are the closest candidates for experiencing intense emotional hardships when faced with dif- ficult problems. Nezu (1989) reports that there is a nuance between possessing a problem-solving skill and practicing an alreadyexisting skill. Though some individuals are equipped with sufficient problem-solving skills, they may still fail to perform effectively. It is a necessity that these individuals learn a constructive problem-solving style (Heppner, Witty, \& Dixon, 2004) since when interpersonal problems are solved through non-constructive methods, such problems trigger worry, anxiety and anger. On the other hand, once problems are solved constructively, positive affect such as happiness arise (Türnüklü \& Şahin, 2004; Öğülmüş, 2001). Positive affect is active pleasure and joy extracted from life, whereas negative affect is the domination of unpleasant emotions such as stress, fear and anger (Gençöz, 2000).

Murray et al. (1990) conducted a research on such positive affect. Upon comparing subjects in positive emotional state and neutral emotional state, the authors demonstrated that subjects in a positive emotional state provided more accurate results in a variety of opinion scales and since they could make more creative associations, these subjects were more flexible. A general analysis of the findings revealed that the differentiation in the emotional state left an effect on problem-solving performance. While such an effect was in the negative direction amongst groups with negative affect, it manifested a positive direction amongst groups with positive affect (Erdoğan, 2009). Picard et al. (2004) argues that positive mood does not provide only one benefit, which can be limited to feeling happy, positive mood also contributes significantly to cognitive aspects such as thinking multidimensionally, creativity and flexibility in problem solving and effective decision making (Gömleksiz \& Kan, 2012). It 
has been reported, on the other hand, that once individuals exhibit higher amounts of negative problem orientations, they are also likely to exhibit greater negative affect in everyday life. The Social problem-solving model claims that once people entertain positive problem orientation, they are better at creating and demonstrating more effective problem-solving strategies. Positive problem orientation motivates the individual to attempt problem solving, improving positive affect in the process (D'Zurilla, Oliveras, \& Pujol, 2011).

Studies probing into the relation between social problem-solving skills and emotional state reveal that there are significant relationships between social problem-solving skills and emotions in children. According to the findings of a research study dealing with the relations between interpersonal problem solving and anger, negative problem orientation is a significant explanation of persistent anger, anger internalization and anger management. Consistent with the negative problem orientations of students, their persistent anger, anger internalization and externalization behaviors increased, while anger control management behaviors diminished. However as the constructivist problem-solving skill of students rose, a decrease has been witnessed in their persistent anger and anger internalization behaviors, while their anger control management behaviors increased (Arslan, 2010; Bedel, 2011). In a relevant study, it has been manifested that exhibiting avoidance and lackof-confidence problem-solving skill, experiencing intense anger when one is not taken seriously and is being criticized, expressing this anger through passive-aggressive or aggressive behaviors and internalizing anger in interpersonal relations are all risky traits driving an individual to suicide (Şahin \& Batıgün, 2009; Batıgün \& Şahin, 2003). An experimental study conducted by Steinhardt and Dolbier (2008) showed that people with good problem-solving skills employ much effective coping mechanisms and they go through higher positive affect as a protective factor. Shure and Spivack (1982) found that children who participated in cognitive problem-solving intervention enhanced their social adaptability and decreased their emotional distress, social withdrawal, impulsive, insensitive, and aggressive behavior as they acquired solutionbased thinking style (Özcan \& Öğülmüş, 2010). The ultimate target of social problem-solving model is obtaining better results within problematic situations and decrease emotional distress (D'Zurilla et al., 2004; D'Zurilla \& Chang, 1995).

The relationship between social problemsolving skills and anxiety state has been a subject of interest for many researchers. Köroğlu (2012) makes a distinction between compliant and disturbing emotions. He states that while worrying is a compliant negative emotion, anxiety is a disturbing emotion. Each individual faces challenges in life. What matters is not whether or not the person faces challenges but the way s/he copes with such hardships. Not only physical but also mental health of the person who is incapable of managing hardships is at stake. A person who is unaware of the way to deal with challenges and problems easily surrenders him/herself to despair and sorrow (Eskin, 2009). Previous research has demonstrated that negative orientation to problems and lack of constructive problem-solving abilities have resulted in an increase in anxiety levels. In one example, Belzer, D’Zurilla, and MaydeuOliveras (2002) found that negative orienta- 
tion to problems, lack of rational problemsolving abilities and impulsive-inattentive problem-solving styles are associated with anxiety levels. In other examples, problemsolving confidence and personal control factors were also found to be associated with anxiety (Davey, 1996; Wang, 1997; quot., Heppner et al., 2004). As the state and persistent anxiety levels of students rise, their confidence in problem-solving skills falls. While their confidence in problem-solving skill rises, the state and persistent anxiety levels fall (Karataş, 2011).

Similarly, individuals with negative problem orientations are much more worried and report greater numbers of health complaints in their daily life (Baker, 2006; Elliot, Herrick, MacNair, \& Harkins, 1994). Hamarta's (2009) research findings revealed that social anxiety's interpersonal problem solving has a positive relationship with negative problem orientation, and a negative relationship with constructivist problem solving. In addition, interpersonal problem solving is a significant variable for social anxiety (ErenGümüş, 2010). In a social problem-solving skill there exists a significant relationship between positive orientation and low anxiety score (Siu \& Shek, 2009). It is demonstrated that high anxiety is accompanied by negative beliefs regarding one's own problem-solving skill (Parkinson \& Creswell, 2011). In a different research it has been put forth that signs of high anxiety, low perception of familial social support and practicing the "hurried style", which is another problem-solving pattern, become significant risk factors in suicidal ideations (Özgüven, Soykan, Haran, \& Gençöz, 2003). A study conducted by Kaufmann and Vosburg (1997) demonstrates that parallel to the performance rise in a person's ana- lytical problem-solving task, a decrease in their anxiety level is observed.

The current study consisted of high school students. Biological, cognitive, and social changes within this age period may bring about emotional distress as well. As a result of this emotional distress, an adolescent may experience an increase in interpersonal conflicts with his/her family and environment. The adolescent may also have difficulty in regulating emotions within these conflicts. Interpersonal problems increase the tendency to impulsive and excessive reactions (Yavuzer, 2000). Students' approaches, negative emotions, and anxiety levels within their interpersonal problems are the core issues for school counselors. Thus, the findings of the current study are expected to help school counselors in designing preventive guidance and counseling programs in schools. Most of the previous research on the associations between problem solving and affectivity and anxiety were conducted with adult populations, it is thus appropriate to further explore these associations in adolescent populations due to their critical effects during adolescence. In light of the above-listed explanations, the objective of the current research is to determine whether the relationships between interpersonal problem solving, positive-negative affect and anxiety levels and interpersonal problem-solving orientation and skills significantly predict positive-negative affect and anxiety levels. It is projected that findings of the present study shall provide significant contributions to the limited numbers of relevant literature studies concerning preventive and developmental guidance works aimed towards interpersonal problem solving, affect and anxiety levels of the compliance issues witnessed during the development periods of adolescents. 


\section{Method}

\section{Participants}

This research population is composed of high school students from Konya, Aksaray and Niğde, which are cities in central Turkey. Research sampling is comprised of ten high school students selected via the random clustering sampling method. There is a total of 336 students: (115) ninth graders, (131) tenth graders, (61) eleventh graders and (29) twelfth graders. 175 students are girls and 159 are boys. Two students did not reveal their gender. Age interval of students varies between 14-19 and mean age is 16.23 $(S D=1.04)$.

\section{Instruments}

Interpersonal Problem Solving Inventory (Çam \& Tümkaya, 2008). Interpersonal Problem Solving Inventory has been developed based on social problem-solving orientation to measure individuals' orientation to interpersonal problems. This Inventory is the only measure of problem-solving for the ages of 14-17. IPSI is a 5-point Likert scale consisting of 50 items developed to measure problem-solving orientation and skills ( $1=$ not appropriate at all, $5=$ totally appropriate). The scale has a total of five subscales: Negative Problem Orientation (NPO), Constructivist Problem Solving (CPS), Lack of Confidence (LC), Avoiding Responsibility (AR) and Insistent-Persevering Orientation (IPO). Sample items include "I feel helpless when I have a problem" for the NPO subscale, "I try to find alternative solutions for a problem I face" for the CPS subscale, "When I have a problem, I doubt that I can solve it" for the LC subscale, "When I have a problem with somebody, I don't struggle to change the situation unless he/she apologizes" for the AR subscale, and "When I have a problem, I insist on finding the solution until I solve it" for the IPO subscale. Results of confirmatory factor analyses supported a five-factor structure of the IPSI $\left(\chi^{2} / \mathrm{df}=1.97\right.$, $\mathrm{RMSEA}=.047, \mathrm{NNFI}=.94, \mathrm{CFI}=.95)$. High score received from each subscale indicates the extent of the relationship with interpersonal problem solving. Internal consistency Cronbach alpha coefficients of IPSI's subscale scores are NPO $=.89, \mathrm{CPS}=.87$, $\mathrm{LC}=.67, \mathrm{AR}=.68$ and $\mathrm{IPO}=.70$. Test-retest correlation values of inventory have been determined to vary between .67 and .84 . The Inventory's validity and reliability tests conducted on high school students have demonstrated that five subscales have the adequate properties to measure interpersonal problem-solving orientations and behaviors (Çam \& Tümkaya, 2008).

Positive and Negative Affect Schedule (Watson, Clark, \& Tellegen, 1988). It is a 5point Likert scale consisting of 20 items developed to measure positive affect and negative affect, 10 items being positive and 10 items being negative descriptions. Turkish adaptation of the scale was made by Gençöz (2000), who determined, upon conducting a factor analysis, that as in the case in original form, the items are dominantly weighted under positive and negative affect factors. For positive and negative affect respectively, internal consistency of the scale has been detected as .83 and .86; test-retest consistency has been respectively detected as .40 and .54. The scores to be received on the scale for each single affect vary between 10 and 50. High score or low score received for each single affect indicates the scantiness 
or ampleness of the relevant affect's intensity. Within the scope of the current research, an exploratory factor analysis has been conducted to test the construct validity of the scale for the 14-17 age group. In this analysis it has been observed that 10 positive items and 10 negative items proposed in the scale are distributed between two relevant factors; factor loads varied between .42 and .73 and two factors collectively explained $46 \%$ of total variance. Additionally, internal consistency of the scale has been detected as .79 and .77 for positive and negative affect respectively. In an exploratory factor analysis of the scale, conducted by Eryllmaz and Ercan (2011) for the 14-17 age group, it has been determined that the explained variance $(54.66 \%)$ reached a two-dimensional scale in the original structure. It has thus been concluded that internal consistency coefficients, calculated for the reliability of subdimensions of the scale, are between a .71 and .79 interval for all age groups.

Trait Anxiety Inventory (Spielberger, Gorsuch \& Lushene, 1970). The scale has been developed by Speilberger et al. with the purpose of designating anxiety levels. Turkish adaptation of the scale was done by Öner and LeCompte. TAI consists of 20 items. Turkish validity and reliability adaptation was completed by Öner (1977) and Cronbach alpha coefficient was identified as $0.83-0.87$. In the trait anxiety scale there are four choices for each item "always (1), sometimes (2), often (3) and almost always (4)". In this part there are 7 reversed statements (24, $26,27,30,33,36$ and 39 . items). In the evaluation, the total score of reversed items is subtracted from the total score of direct items, a fixed number (35) is added and the sum result indicates the trait anxiety score. The scores obtained from this scale vary between
20 and 80 . Anxiety level is graded as follows: for 0-19 scores "none", for 20-29 scores "mild", for 40-59 scores "medium", for 60-79 scores "heavy" and for 80 scores "very heavy". The scale is applied to individuals over the age of 14 years (Öner, 2008).

\section{Procedures}

The scales employed in the present research were distributed by counselor teachers during class hours. Prior to the participation, students were briefed about the research objective and only volunteering students were selected. In order to examine potential relations among the research variables, which are interpersonal problem solving, positive-negative affect and anxiety scores, the Pearson Moments Multiplication Correlation coefficients were calculated. In order to determine the explanatory ratio of interpersonal problem solving on the positivenegative affect and anxiety level, the Multiple Regression Analysis was employed. Their relative explanatory levels were compared via standardized Beta values $(\beta)$.

\section{Results}

Correlations regarding interpersonal problem inventory, positive-negative affect and trait anxiety inventory employed in present research are presented in Table 1.

Table 1 displays that there is a medium level and positive relation between negative problem orientation and negative affect $(r=.452$, $p<0.01$ ) of interpersonal problem solving; and a medium level and positive relation with trait anxiety $(r=.592, p<0.01)$. There is a medium level and positive relation between constructivist problem solving and positive affect $(r=.241, p<0.01)$; a low level and 
Table 1. Correlations among interpersonal problem-solving, positive and negative affect and trait anxiety

\begin{tabular}{lccccccr}
\hline Variable & 1 & 2 & 3 & 4 & 5 & 6 & 7 \\
\hline $\begin{array}{l}\text { 1. Negative orientation to the } \\
\text { problem }\end{array}$ & - & & & & & & \\
2. Constructive problem solving & .075 & - & & & & & \\
3. Lack of self-confidence & $.424^{* *}$ & $.147^{* *}$ & - & & & & \\
4. Unwilling to take responsibility & $.324^{* *}$ & $.150^{* *}$ & $.365^{* *}$ & - & & & \\
5. Insistent-persevering orientation & $.140^{*}$ & $.521^{* *}$ & -.100 & -.029 & - & & \\
6. Positive affect & -.026 & $.241^{* *}$ & -.005 & .070 & $.364 * *$ & - & \\
7. Negative affect & $.452^{* *}$ & $-.148^{* *}$ & $.283^{* *}$ & $.192^{* *}$ & $-.108^{*}$ & -.014 & - \\
8. Trait Anxiety & $.592^{* *}$ & -.057 & $.349^{* *}$ & $.308^{* *}$ & .040 & -.036 & $.628^{* *}$ \\
\hline$* p<.05, * * p<.01$ & & & & & & & \\
\hline
\end{tabular}

negative relation with negative affect $(r=$ $-.148, p<0.01)$. There is a medium level and positive relation between lack of confidence and negative affect $(r=.283, p<0.01)$; a medium level and positive relation with trait anxiety $(r=.349, p<0.01)$. There is a low level and positive relation between avoiding responsibility and negative affect $(r=.192$, $p<0.01)$; medium level and positive relation with trait anxiety $(r=.308, p<0.01)$. There is a medium level and positive relation between insistent-persevering orientation and positive affect $(r=.364, p<0.01)$; a low level and positive relation with negative affect $(r=$ $-.108, \mathrm{p}<0.01)$.

In order to determine the predictive level of interpersonal problem-solving variables on positive affect, multilinear regression analysis was carried out and the obtained results are in Table 2.
Table 2 shows that all variables detected as predictive variables collectively predict positive affect on a significant level $(p<.001)$ and explain about $16 \%$ of the variance in positive affect. As relevant Beta values are examined it surfaces that the strongest predictor of positive affect is insistent-persevering orientation $(\beta=.341)$ ensued by negative problem orientation $(\beta=-.147)$ and avoiding responsibility $(\beta=.119)$ variables.

A multilinear regression analysis was carried out to determine the predictive level of interpersonal problem-solving variables on negative affect and the obtained results are in Table 3 .

Table 3 shows that all variables detected as predictive variables collectively predict negative affect on a significant level $(p<.001)$ and explain about $25 \%$ of the variance in negative affect. As relevant Beta values are 
Table 2. Multiple regression analysis for the prediction of positive affect

\begin{tabular}{lccccc}
\hline Variable & $B$ & $S H_{B}$ & $\beta$ & $T$ & \multicolumn{1}{l}{$P$} \\
\hline 1. Negative orientation to the problem & -.079 & .031 & -.147 & -2.521 & .012 \\
2. Constructive problem solving & .062 & .037 & .102 & 1.697 & .091 \\
3. Lack of self-confidence & .086 & .080 & .063 & 1.076 & .283 \\
4. Unwilling to take responsibility & -.184 & .086 & .119 & 2.137 & .033 \\
& & & & & \\
5. Insistent-persevering orientation & .531 & .093 & .341 & 5.704 & .000 \\
\hline $\begin{array}{l}R=.401 R^{2}=.161 \\
F_{(5,330)}=12.628 p=.001\end{array}$ & & & & & \\
\hline
\end{tabular}

Table 3. Multiple regression analyses for the prediction of negative affect

\begin{tabular}{|c|c|c|c|c|c|}
\hline Variable & $B$ & $\mathrm{SH}_{B}$ & $\beta$ & $T$ & $P$ \\
\hline 1. Negative orientation to the problem & .272 & .034 & .446 & 8.093 & .000 \\
\hline 2. Constructive problem solving & -.082 & .039 & -.119 & -2.087 & .038 \\
\hline 3. Lack of self-confidence & .100 & .085 & .065 & 1.167 & .244 \\
\hline 4. Unwilling to take responsibility & .005 & .092 & .003 & .056 & .955 \\
\hline 5. Insistent-persevering orientation & -.180 & .100 & -.102 & -1.804 & .072 \\
\hline $\begin{array}{l}R=.499 R^{2}=.249 \\
F_{(5,330)}=21.885 p=.001\end{array}$ & & & & & \\
\hline
\end{tabular}

examined it surfaces that the strongest predictor of negative affect is negative problem orientation $(\beta=.446)$ ensued by constructivist problem-solving $(\beta=-.119)$ variable.

A multilinear regression analysis was carried out to determine the predictive level of interpersonal problem-solving variables on trait anxiety and the obtained results are in Table 4.
Table 4 shows that all variables detected as predictive variables collectively predict trait anxiety on significant level $(p<.001)$ and explain about $38 \%$ of the variance in trait anxiety. As relevant Beta values are examined it surfaces that the strongest predictor of trait anxiety is negative problem orientation $(\beta=.531)$ ensued by avoiding responsibility variable. 
Table 4. Multiple regression analysis for the prediction of trait anxiety

\begin{tabular}{|c|c|c|c|c|c|}
\hline Variable & $B$ & $\mathrm{SH}_{B}$ & $\beta$ & $T$ & $P$ \\
\hline 1. Negative orientation to the problem. & .325 & .031 & .531 & 10.583 & .000 \\
\hline 2. Constructive problem solving & -.056 & .036 & -.081 & -1.563 & .119 \\
\hline 3. Lack of self-confidence & .122 & .078 & .079 & 1.561 & .120 \\
\hline 4. Unwilling to take responsibility & .168 & .084 & .096 & 1.992 & .047 \\
\hline 5. Insistent-persevering orientation & .034 & .091 & .019 & .370 & .711 \\
\hline $\begin{array}{l}R=.614 ; R^{2}=.377 \\
F_{(5,330)}=39.999 ; p=.001\end{array}$ & & & & & \\
\hline
\end{tabular}

\section{Discussion}

These research findings manifest significant relationships among negative problem orientation dimensions, negative affect and trait anxiety of interpersonal problem solving; between constructivist problem solving and positive affect; among lack of confidence, negative affect and trait anxiety; between avoiding responsibility and trait anxiety; between insistent-persevering orientation and positive affect. Furthermore, analyzing which variables explain positive affect revealed that insistent-persevering orientation, negative problem orientation and avoiding responsibility are the predictors of positive affect. Insistent-persevering orientation, which is a component of the constructivist problem-solving skill, represents an individual's persistent effort to solve problems in his/her interpersonal relations (Çam \& Tümkaya, 2007). These people are well aware that interpersonal problem solving requires time and effort. While encountering interpersonal problems, if an individual exhibits positive orientation, takes responsibility in solving problems and holds a insistent-persevering orientation, then the individual is more motivated towards problem solving and experiencing positive affect. Conducted researches have manifested that, as opposed to persistent orientation, exhibiting an avoidance and lack of confidence in problem solving might be influential in increasing intense negative affect when one is criticized, which is also a risky situation tempting suicidal ideation (Şahin \& Batıgün, 2009; Batıün \& Şahin, 2003). Insistent-persevering is positively related to positive affect, while negative orientation to the problem and avoiding responsibility are negatively related to positive affect. As negative problem orientation and avoiding responsibility rise, positive affect falls. One of the most salient factors in constructivist problem solving is to keep persevering during the problem solving process.

According to a different finding, the strongest predictor of negative affect is negative 
problem orientation. Problem orientation involves a variety of points: one's own problem solving skills, the way one feels and thinks about everyday problems, and emotional and cognitive charts (Arslan, Hamarta, Arslan, \& Saygın, 2010; Arslan, 2005). It has been reported that once people possess negative orientation to any problem, they are imbued with greater quantities of negative emotion (Baker, 2006). Such negative emotions may pose hindrance to a person's problem solving skills (Köroğlu, 2012). In a study conducted by Arslan (2010), it has been detected that as negative problem orientation of students increase trait anger, internalizing anger and externalizing anger behaviors also rise whilst anger control behaviors weaken. According to the social problem solving model developed by D'Zurilla and Goldfried (1971), if a person holds a negative orientation to his/her interpersonal problem, considers problems as life threatening events, lacks confidence in his/her problem solving skills and gets easily frustrated, this person is more likely to experience negative affect. As revealed in Murray's (1990) research, the change in emotional state leaves an effect on problem solving performance (Erdoğan, 2009). Positive orientation towards interpersonal problems and possessing constructivist problem-solving skills enable individuals to employ further effective coping mechanisms, hence allowing them to experience positive emotions as regards solving real problems. Treated collectively with the findings of previous research, the obtained findings underline that strong relations exist among problem orientation, affect and problem-solving skills (Elliott et al., 1994; Eskin, 2009; Y1lmaz, 2012). Consistent with former findings, while constructivist problem-solving skills increase, negative emotions de- crease. People possessing constructivist problem-solving skills consider problems as natural components of everyday life. They put their trust in the solubility of problems and feel self confident in solving challenges one way or another. Instead of avoiding the problems, they take an active role and responsibility in problem solving. Hence this ability prevents the individual from experiencing negative emotions when frustrated with problems and drives positive emotions.

In a different finding, it is possible to believe that the predictor of persistent anxiety is negative problem orientation and avoiding responsibility. As explained hereinabove, negative problem orientation involves negative orientation towards experienced problems and inclination towards negative thinking. Once adolescents adopt negative orientation and avoid responsibility in their interpersonal problems, the anxiety level they experience rises. It is quite natural that people can face difficulties and inevitably experience anxiety when faced with problems. They may also go through emotional hardships when they encounter hard-to-solve problems. What really matters at this point is learning how to deal with problems and instead of running away accepting one's own responsibility. As people increasingly accept to take on their own responsibilities, their constructivist problem-solving skill and positive orientation towards problems are also strengthened (Bedel, 2011). It is quite an expected outcome that people who have no idea about how to cope with their problems or try to deal with problems via dysfunctional ways develop anxiety as time passes by. In relevant literature, significant relations have been demonstrated between social problemsolving skills and anxiety (Eskin, 2009; Hamarta, 2009; Siu \& Shek, 2009; Wilson, 
Bushnell, Rickwood, Caputi, \& Thomas, 2011). It is considered that once an individual views him/herself as an ineffective problem solver, the state of anxiety expands (Heppner et al., 2004). In a different research conducted by Karataş (2011), a relationship has been manifested between negative problem orientation and anxiety. It has also been demonstrated that as students' confidence in their problem-solving skill rises their anxiety level diminishes. The study conducted by Parkinson and Creswell (2011) is also supportive of our research findings. According to another research finding, a significant relationship exists between high anxiety and one's negative views of his/her problemsolving skills. Anderson, Goddard and Powell's (2007) research also revealed that, compared to the control group, the test group with anxiety manifested a negative orientation towards problem solving and developed a less effective strategy towards problem solving.

An overall evaluation of research findings indicates that there is a significant relationship among adolescents' interpersonal problem-solving skills, their positive - negative affect and anxiety levels. Consistent with research findings it can be argued that in lowering negative affect and anxiety levels in adolescents, acquisition of interpersonal problem-solving orientation gains remarkable importance. Consequently, in preventive guidance and psychological counseling services offered in educational institutions particularly, activities and workshops aimed at teaching adolescents how to gain positive interpersonal problem-solving skills and combining the activities with affect and anxiety state measures would be beneficial. It is envisaged that the present research shall contribute significantly to the literature on the social problem-solving model. Current research covering high school students could be reapplied in different groups in order to establish the generalizability of the findings. Another focus could be on the effect of interpersonal problem-solving skills on thinking and other emotions.

Received September 18, 2014

\section{References}

Anderson, R. J., Goddard, L., Powell, J. H. (2007). Social problem-solving processes and mood in college students: An examination of self-report and performance-based approaches. Cognitive Therapy and Research, 33, 175-186.

Arslan, C. (2005). Kişiler arası çatışma çözme ve problem çözme yaklaşımlarının yükleme karmaşıklığı açısından incelenmesi [An investigation of the interpersonal conflict solving and problem solving approaches according to their attribution complexity]. Selçuk Üniversitesi Sosyal Bilimler Enstitüsü Dergisi, 14, 75-93.

Arslan, C. (2010). An investigation of anger and anger expression in terms of coping with stress and interpersonal problem-solving. Educational Sciences: Theory \& Practice, 10(1), 7-43.

Arslan, C., Hamarta, E., Arslan, E., Saygın, Y. (2010). An investigation of aggression and interpersonal problem solving in adolescents. Elementary Education Online, 9(1), 379-388.

Baker, S. R. (2006). Towards an idiothetic understanding of the role of social problem solving in daily event, mood and health experiences: A prospective daily diary approach. British Journal of Health Psychology, 11, 513-531.

Batıgün, A. D., Şahin, N. H. (2003). Can anger, impulsivity, and perceiving oneself as an efficient problem solver be a forerunner of adolescent suicide? Turkish Journal of Psychology, 18(51), 37-52.

Bedel, A. (2011). Kişiler arası sorun çözme beceri eğitiminin ergenlerin sürekli öfke ve öfke ifade tarzlarına etkisinin incelenmesi [Examining the effect of the interpersonal problem solving skills training on the adolescents' trait anger and anger expression styles]. Doctoral thesis, Selçuk Üniversitesi Eğitim Bilimleri Enstitüsü, Konya. 
Belzer, K. D., D’Zurilla, T. J., Maydeu-Olivares, A. (2002). Social problem solving and trait anxiety as predictors of worry in a college student population. Personality and Individual Differences, 33, 573-585

Çam, S., Tümkaya, S. (2007). Developing the interpersonal problem solving inventory (IPSI): The validity and reliability process. Turkish Psychological Counseling and Guidance Journal, 28(3), 95-111.

Çam, S., Tümkaya, S. (2008). Development of interpersonal problem solving inventory for high school students: The validity and reliability process. International Journal of Human Sciences, 5(2), 1-17.

D'Zurilla, T. J., Goldfried, M. R. (1971). Problem solving and behavior modification. Journal of Abnormal Psychology, 78(1), 107-126.

D'Zurilla, T. J., Chang, E. C., Sanna, L. J. (2003). Self-esteem and social problem solving as predictors of aggression in college students. Journal of Social and Clinical Psychology, 22(4), 424-440.

D’Zurilla, T. J., Maydeu-Olivares, A., Gallardo-Pujol, D. (2011). Predicting social problem solving using personality traits. Personality and Individual Differences, 50, 142-147.

D'Zurilla, T. J., Nezu, A. M., Maydeu-Oliveras, A. (2004). Social problem solving: Theory and assesment. In E. C. Chang, T. J. D'Zurilla \& L. J. Sanna, (Ed.), Social problem solving: Theory, research and training (pp. 11-27). Washington DC: American Psychological Association.

D'Zurilla, T. J., Chang, E. C. (1995). The relations between social problem solving and coping. Cognitive Therapy and Research, 19(5), 547-562.

Elliott, T. R., Herrick, S. M., MacNair, R. R., Harkins, S. W. (1994). Personality correlates of self-appraised problem solving ability: Problem orientation and trait affectivity. Journal of Personality Assessment, 63(3), 489-505.

Erdoğan, Ö. (2009). Duygu durumunun problem çözme stratejileri üzerindeki etkileri [The impacts of different moods of success on the strategies of problem solving]. Milli Eğitim Dergisi, $181,252-276$

Eryılmaz, A., Ercan, L. (2011). Investigating of the subjective well-being based on gender, age and personality traits. Turkish Psychological Counseling and Guidance Journal, 4(36), 139. 151.

Eskin, M. (2009). Sorun çözme terapisi [Problemsolving therapy]. Ankara: HYB Basım Yayın.
Gençöz, T. (2000). Positive and negative affect schedule: The validity and reliability process. Turkish Journal of Psychology, 15(46), 19-26.

Gömleksiz, M. N., Kan, A. Ü. (2012). Affectıve dimension in education and effectıve learning. Turkish Studies, International Periodical For The Languages, Literature and History of Turkish or Turkic, 7(1), 1159-1177.

Gümüş, A. E. (2010). Sosyal kaygı ile başa çıkma [Coping with social anxiety]. (Edi: Uğur Öner). Ankara: Nobel Yayın Dağıtım

Hamarta, E. (2009). Examining the social anxiety of adolescents with regards to interpersonal problem solving and perfectionism. Elementary Education Online, 8(3), 729-740. [Online]: http:// ilkogretim- online.org.tr

Heppner, P. P., Witty, T. E., Dixon, W. A. (2004). Problem solving appraisal and human adjustment. The Counseling Psychologist, 32(3), 344428 .

Karataş, Z. (2011). An investigation of problem solving skills and anxiety levels of adolescents who stay in boarding school. Mehmet Akif Ersoy University Journal of Education Faculty, 11(21), 208-222.

Kaufmann, G., Vosburg, S. K. (1997). 'Paradoxical' mood effects on creative problem-solving. Cognition \& Emotion, 11(2), 151-170.

Köroğlu, E. (2012). Düşünsel duygulanımcı davranış terapisi [Rational emotive behavior therapy]. Ankara: HYB yayıncılık.

Öğ̈̈lmüş, S. (2001). Kișiler arası sorun çözme becerileri ve eğitimi [Interpersonal problem-solving skills and training]. Ankara: Nobel Yayın Dağıtım.

Öner, N., Lecompte, A. (1985). Durumluk sürekli kaygl envanteri el kitabl [Manual for state-trait anxiety Inventory]. İstanbul: 2. Baskı, Boğaziçi Üniversitesi Yayınevi.

Öner, N. (2008). Türkiye'de kullanılan psikolojik testlerden örnekler Examples of psychological tests used in Turkey]. İstanbul: 2. Baskı, Boğaziçi Üniversitesi Yayınevi

Özcan, C., Ögülmüş, S. (2010). Contribution of interpersonal cognitive problem-solving strategy to children with attention deficit hyperactivity disorder. TAF Preventive Medicine Bulletin, 9(4), 391-398.

Özgüven, H. D., Soykan, Ç., Haran, S. Gençöz, T. (2003). Importance of problem solving skills, perceived social support, and depression and anxiety symptoms on suicide attempts. Turkish Journal of Psychology, 18(52), 1-11. 
Parkinson, M., Creswell, C. (2011). Worry and problem-solving skills and beliefs in primary school children. British Journal of Clinical Psychology, 50, 106-112.

Siu, A. M. H., Shek, D. T. L. (2009). Social problem solving as a predictor of well-being in adolescents and young adults. Social Indicators Research, 95, 393-406.

Steinhardt, M., Dolbier, C. (2008). Evaluation of a resilience intervention to enhance coping strategies and protective factors and decrease symptomatology. Journal of American College Health, 56(4), 445-453.

Sahin, N. H., Batıgün, A. D. (2009). Testing the probability of a model to predict suicide risk in high school and university students. Turkish Journal of Psychiatry, 20(1), 28-36.

Türnüklü, A., Şahin, İ. (2004). Examining 13-14 years old students' conflict resolution strate- gies. Turkish Psychological Articles, 7(13), 4561.

Wilson, C. J., Bushnell, J. A, Rickwood, D. J., Caputi, P., Thomas, S. J. (2011). The role of problem orientation and cognitive distortions in depression and anxiety interventions for young adults. Advances in Mental Health, 10(1), 52-61.

Y1k1lmaz, M., Hamamc1, Z. (2011). The effect of rational emotive education program on high school students' irrational beliefs and perceived problem solving skills. Turkish Psychological Counseling and Guidance Journal, 4(35), 54-65.

Yılmaz, E. (2012). 60-72 aylık çocukların duyguları anlama becerilerinin sosyal problem çözme becerilerine etkisinin incelenmesi [Studying effect of emotion understanding skills of 60-72 months old children on their social problem solving skills]. Yüksek lisans tezi, Selçuk Üniversitesi Sosyal Bilimler Enstitüsü, Konya.

\title{
VZŤAH MEDZI RIEŠENÍM INTERPERSONÁLNYCH PROBLÉMOV, POZITÍVNYM-NEGATIIVNYM AFEKTOM A ANXIETOU
}

\author{
A. B e d e 1
}

Súhrn: Ciel'om štúdie bolo skúmat' vzt’ah riešenia interpersonálnych problémov, pozitívneho negatívneho afektu a anxiety. Výskumu sa zúčastnilo 336 stredoškolákov, ktorí vyplnili dotazníky Interpersonal Problem Solving Inventory (Çam \& Tümkaya, 2008), Positive and Negative Affect Schedule (Gençöz, 2000), a Trait Anxiety Inventory (Öner, 1977). Štatistická analýza štúdie zahŕn̆ala aj Pearsonov momentový korelačný koeficient a viacnásobnú regresnú analýzu. Výsledky ukázali signifikantné korelácie medzi negatívnym zameraním na problém, negatívnym afektom a anxietou, ako aj signifikantné korelácie medzi konštruktívnym riešením problémov, neodbytne-vytrvalou orientáciou a pozitívnym afektom. Viacnásobná regresná analýza naznačila, že $\mathrm{v}$ rámci negatívneho afektu a anxiety, bola najsilnejším prediktorom negatívna orientácia na problém. Na základe týchto výsledkov sme navrhli plánované intervencie na zlepšenie schopností riešenia interpersonálnych problémov u študentov pri individuálnych a skupinových činnostiach a predstavili návrhy pre budúci výskum. 